\title{
Staphylococcus succinus
}

National Cancer Institute

\section{Source}

National Cancer Institute. Staphylococcus succinus. NCI Thesaurus. Code C124406.

A species of coagulase-negative, Gram-positive coccoid bacterium in the order Bacillales. 